\title{
The Effect of Gamma Irradiation on the Growth Rate of Phosphorus and Potassium Solubilizer Multifunctional Microbes
}

\author{
Desak Ketut Tristiana Sukmadewi ${ }^{1 *}$, Iswandi Anas ${ }^{2}$, Ania Citraresmini ${ }^{3}$ \\ ${ }^{1}$ Agrotechnology Department, Faculty of Agriculture, Warmadewa University, Denpasar, Bali, Indonesia \\ ${ }^{2}$ Department of Soil Science and Land Resources, Faculty of Agriculture, IPB University, \\ Jl. Meranti Kampus IPB Dramaga, Bogor 166680, Indonesia \\ 3 Isotope and Radiation Application Center, National Nuclear Energy Agency of Indonesia, \\ Lebak Bulus Raya Street 49, South Jakarta 12440, Indonesia. \\ *tristianasukmadewi@yahoo.com
}

\begin{abstract}
Phosphorus $(P)$ and potassium $(K)$ solubilizing microbes have an important role in accelerating the solubility process of $P$ and $K$ sources which are difficult to dissolve. The purpose of this research was to study the effect of gamma irradiation on the growth rate of $P$ and $K$ solubilizer multifunctional microbes. The microbes used in this study were P and K solubilizer multifunctional bacteria BPK 5 (Staphylococcus pasteuri) and the $P$ and $K$ solubilizer multifunctional fungi FPF 4 (Aspergillus costaricaensis). The microbes were irradiated with gamma rays at a dose of $0 ; 1 ; 2.5 \mathrm{kGy}$. Tests of bacterial growth rate were observed through the optical density measurement and Total Plate Count (TPC), while fungi were observed through measurement of colony diameter and TPC. Gamma irradiation effects increasing the growth rate of $P$ and $K$ solubilizer multifunctional bacteria (1.0 BPK 5 and 2.5 BPK 5) based on optical density values. Based on the TPC result, the increase in bacterial growth rate tended to be shown by isolates 2.5 BPK 5. The effect of gamma irradiation on the growth rate of fungi was indicated by the colony diameter of the isolate 1.0 BPK 5 which was wider than the wild-type isolate and isolate 2.5 BPK 5. TPC results on fungi also showed that gamma irradiation affected the growth rate of fungi at 24, 96, 120, and 288 hours incubation time.
\end{abstract}

Keyword: Gamma irradiation; microbe; growth and fertilizer

\section{Introduction}

Microbials in the soil that have many important roles are grouped into Plant Growth Promoting Rhizobacteria (PGPR). These microbial groups can help increase plant growth and can interact with plants by colonizing plant roots [1]. The application of PGPR can affect plant growth, both directly and indirectly. The direct effect of PGPR is based on its ability to provide and to mobilize or facilitate the absorption of various nutrients in the soil, as well as to synthesize and change phytohormone concentrations. The effect of PGPR indirectly is the ability of the PGPR to suppress pathogenic activity by producing various compounds or metabolites, such as antibiotics and siderophores [2].

This research will be focused on $\mathrm{P}$ and $\mathrm{K}$ solubilizer multifunctional microbes. $\mathrm{P}$ and $\mathrm{K}$ solubilizer multifunctional microbes are focused because until now the fulfillment of $\mathrm{P}$ and $\mathrm{K}$ nutrients in agricultural land in Indonesia is generally through the addition of inorganic fertilizers [3]. Research by [4] also reported that intensive agricultural practices that routinely provide inorganic fertilizers with high doses and intensities lead to the accumulation of phosphorus $(\mathrm{P})$ and potassium (K). Most of the $\mathrm{P}$ and $\mathrm{K}$ elements that have been accumulated are not available for plant growth. 
The need for inorganic fertilizers is currently still being met through imports from various countries. Indonesia is a country that is rich in natural sources of $\mathrm{P}$ and $\mathrm{K}$ such as $\mathrm{P}$ rock as well as feldspar and mica. However, these $\mathrm{P}$ and $\mathrm{K}$ sources cannot be used by plants because they require a long time for the dissolving process. Natural sources of $\mathrm{P}$ and $\mathrm{K}$ are not always effective because of their low solubility or reactivity [5]. Based on this, an activator that can accelerate the solubility process of $\mathrm{P}$ and $\mathrm{K}$ is needed. One of them is the mechanism of dissolving $\mathrm{P}$ and $\mathrm{K}$ by Microbial.

Microbials that can accelerate the solubility of $\mathrm{P}$ and $\mathrm{K}$ are generally applied as biofertilizers. Biofertilizers that have good quality are biofertilizers that, when applied, can compete or adapt to indigenous microbes in the soil [6]. One of the factors that influence the speed of adaptation of this microbe is the growth rate to dominate the area around the roots. Therefore need an effort to increase the rate of growth of these microbes. One of the efforts that can be done is mutation induction with gamma irradiation.

Gamma irradiation has been widely used in sterilization and mutagenesis especially for plant breeding and plant protection. Gamma irradiation has been used in agriculture to induce mutagenesis in microbes such as to increase antagonistic ability and also to increase the ability of enzyme production for fermentation purposes. In agriculture, this approach is usually focused on crop protection [7]. The research of [8] showed that several doses of gamma irradiation were able to increase the ability of microbes mutants to dissolve phosphate and potassium. The BPK5 mutant at a dose of $7.5 \mathrm{kGy}$ was able to dissolve phosphate (165.67 ppm) and potassium $(18.89 \mathrm{ppm})$ which was higher than the control. The FPF 4 mutant at a dose of $2.5 \mathrm{kGy}$ was able to dissolve phosphate (418.15 ppm) higher than the control, while the FPF 4 mutant was able to dissolve potassium (13.90 $\mathrm{ppm}$ ) higher than the control at a dose of $15 \mathrm{kGy}$. Based on this, research related to the effect of gamma irradiation on the growth rate of microbe has not been further reviewed, so this research aimed to study the effect of gamma irradiation on the growth rate of $\mathrm{P}$ and $\mathrm{K}$ solubilizer multifunctional microbes.

\section{Material and Methods}

\subsection{Irradiation of $\mathbf{P}$ and $K$ Solubilizer Multifunctional Microbes}

The microbial used in this study consisted of $\mathrm{P}$ and $\mathrm{K}$ solubilizer multifunctional bacteria BPK 5 (Staphylococcus pasteuri (Figure 1)) and the P and K solubilizer multifunctional fungi FPF 4 ( Aspergillus costaricaensis (Figure 2)). The microbes used in this study get freeze-drying treatment. The microbial was irradiated with gamma rays from the Co-60 source at a dose of $0 ; 1 ; 2.5 \mathrm{kGy}$ using a gamma cell irradiator 220 . The dosage rate used is $6.57 \mathrm{kGy} /$ hour. The dose that samples received was considered to be the same as the target dose given because of the small sample size. The irradiated bacteria and fungi were then diluted (diluted) and inoculated using the spread plate method into specific Pikovskaya and Alexandrov media [8].

\subsection{Growth Rate Test of $\mathbf{P}$ and K Solubilizer Multifunctional Microbes}

Based on the results of irradiation, two bacterial isolates were found to be used further, namely 1.0 BPK 5 and 2.5 BPK 5 isolates. The growth rate of these isolates would be compared with the wild-type isolates (isolates that were not irradiated). In the test of $\mathrm{P}$ and $\mathrm{K}$ solubilizer multifunctional bacteria, the bacteria used were grown on Nutrient Broth (NB) media [9]. The optical density of bacteria was measured using a spectrophotometer at $0,3,24,28,46,48$, and 50 hours incubation time. Total Plate Count (TPC) was carried out on Nutrient Agar (NA) media at 0, 1, 3, 5 hours, 22, $24,26,28,48$, and 50. Two isolates of fungi that had been irradiated were further used, namely 1.0 FPF 4 and 2.5 FPF 4 isolates. In the test of the growth rate of $\mathrm{P}$ and $\mathrm{K}$ solubilizer multifunctional 
bacteria on solid media Potato Dextrose Agar PDA) [10]. The Petri dishes used to grow the fungus have a diameter of $9 \mathrm{~cm}$. The diameter of the fungus was calculated at $0,18,24,42,48,66,72,90$, $96,114,120,138,144,162$ hours incubation time. Observation of fungal growth was also carried out using the TPC method. Fungi were grown on Potato Dextrose Broth (PDB) media and then TPC was carried out on PDA media. TPC was carried out at 0, 24, 48, 72, 96, 120, 216, 288 hours.

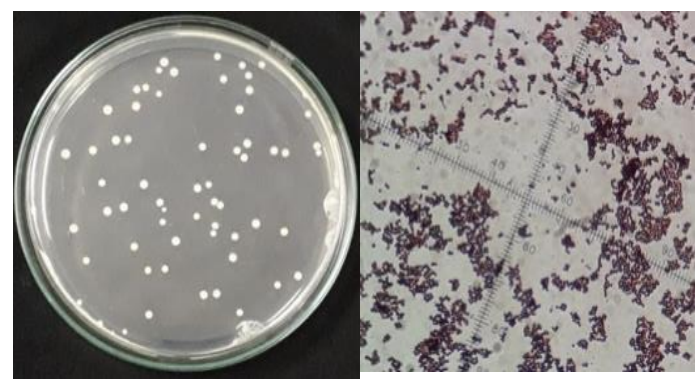

Figure 1

Morphology of P and K solubilizer multifunctional bacteria BPK 5 (Staphylococcus pasteuri)

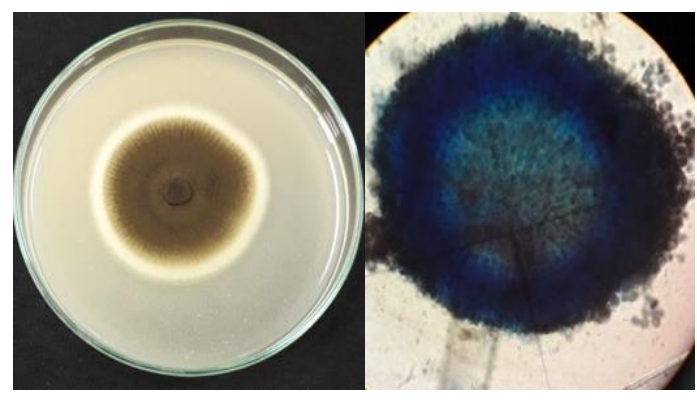

Figure 2

Morphology of P and K solubilizer multifunctional fungi FPF 4 (Aspergillus costaricaensis)

\section{Results and Discussion}

\subsection{Results}

\subsubsection{Effect of Gamma Irradiation on Growth Rate of $\mathbf{P}$ and $\mathbf{K}$ Solubilizer Multifunctional Bacteria}

Based on the observations of the growth of the wild-type isolates and bacteria that had been irradiated, it was seen that isolate 2.5 BPK5 produced the highest optical density at the 3 to the 50 hour incubation time (Figure 3). 1.0 BPK5 isolate also showed a higher optical density compared to the wild-type isolate at the 22 to 50 hour incubation time. The higher optical density indicated that the microbe population was higher at the observed hours. Based on the results obtained, it shows that the growth of the isolates that have been irradiated is faster than the wild-type isolates. Therefore, this shows that gamma irradiation affects the accelerated growth of the $\mathrm{P}$ and $\mathrm{K}$ solubilizer multifunctional bacteria. Based on the results of TPC on NA media (Figure 4), it shows that the highest TPC results in 2.5 BPK 5 isolate at 3 to 46 hours incubation time. During the 48 to 50 hours of observation, the highest yield was found in the wild-type isolates. 1.0 BPK 5 isolate showed lower TPC results compared to the wild type and $2.5 \mathrm{BPK} 5$ isolates. 


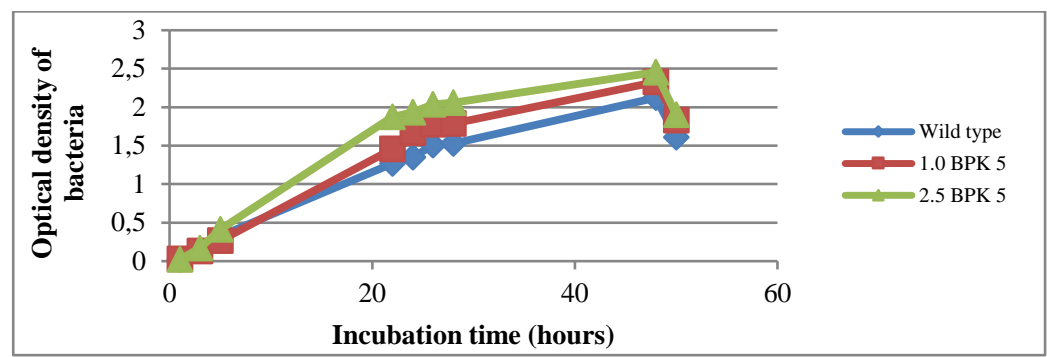

Figure 3

Growth of wild type bacteria and irradiated bacteria (1.0 BPK5 and 2.5 BPK5) based on optical density on NB media with an incubation time of 50 hours

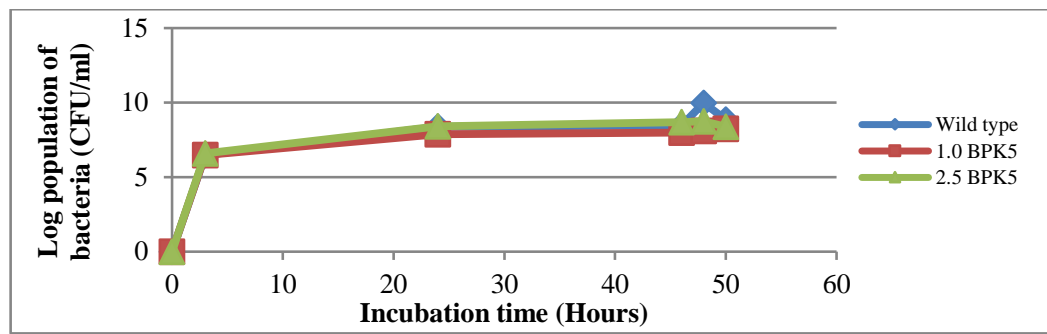

Figure 4

Growth of the wild type bacteria and irradiated bacteria (1.0 BPK5 and 2.5 BPK5) based on the results of the TPC on NA media with an incubation time of 50 hours

\subsubsection{Effect of Gamma Irradiation on Growth Rate of P and K Solubilizer Multifunctional Fungi}

Based on the measurement results, the diameter of the fungus showed that the widest diameter was produced by the irradiated isolate, namely, isolate 1.0 BPK5. 1.0 BPK 5 isolate showed a tendency to have a wider diameter compared to the wild type isolate and 2.5 BPK 5 isolate at the observation time from 18 hours to 210 hours (Figure 5). This wider diameter indicates that the 1.0 BPK 5 isolate had a higher growth rate than the wild-type isolate and the 2.5 BPK 5 isolate. The results obtained indicated that gamma irradiation affected the growth rate of the fungal isolate, in this case increasing the growth rate of the 1.0 BPK5 isolate.

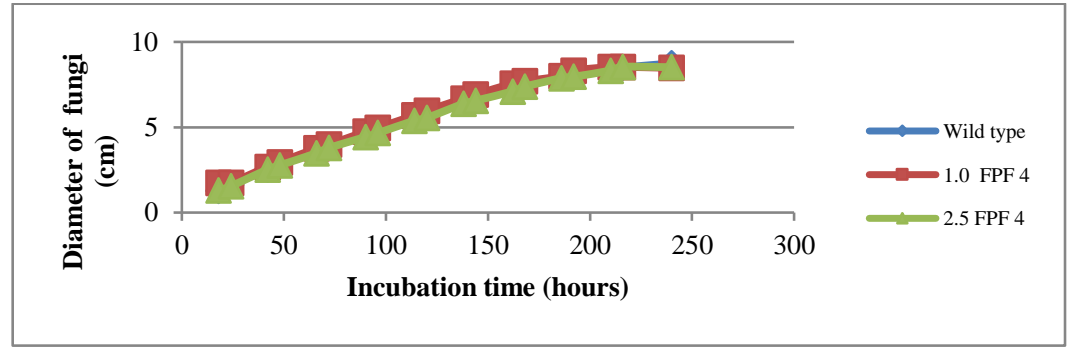

Figure 5

Growth of wild-type fungi and irradiated fungi (1.0 FPF 4 and 2.5 FPF 4) on PDA media with an incubation time of 216 hours.

Based on the results of the TPC of isolates grown on PDB, the population of 1.0 BPK 5 isolates was higher than the wild type isolates at 96 and 120 hours incubation time. 2.5 BPK 5 isolate showed a higher population than the wild type isolates at 24, 96, 288 hours incubation time (Figure 6). A higher population indicates that the growth is faster. Overall results show that gamma irradiation has an influence on the growth rate of fungi at certain hours. 


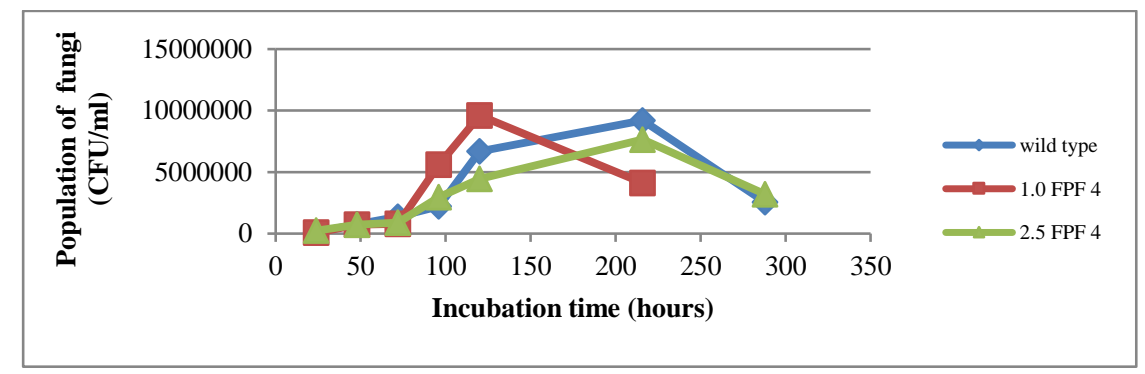

Figure 6

Growth of wild type fungi and irradiated fungi (1.0 FPF 4 and 2.5 FPF 4) based on the results of $\mathrm{TPC}(\mathrm{CFU} / \mathrm{ml})$ on PDA media with an incubation time of 216 hours

\subsection{Discussion}

Based on the overall results obtained, it shows that gamma irradiation affects the growth rate of $\mathrm{P}$ and $\mathrm{K}$ solubilizer multifunctional microbe. Observation of the growth rate of bacteria using optical density shows the tendency of gamma irradiation results to increase the growth rate of the bacteria, both 1.0 BPK5 and 2.5 BPK5 isolates. In growth observations based on the results of TPC 2.5 BPK5 isolate showed a higher colony than wild-type isolate and 1.0 BPK5 isolate. Different results were shown in the optical density and TPC measurements because in the optical density measurement both living and dead bacteria, were all measured. In the calculation based on the results of TPC, the colony number data obtained were based on the number of living bacterial cells. The results of observing the growth rate of fungi by measuring the colony diameter showed that gamma irradiation could increase the growth rate of fungi 1.0 BPK5.

Based on the calculation of the TPC results showed that gamma irradiation increased the growth rate of 1.0 FP4 and 2.5 FPF4 fungi at certain hours. Based on the results obtained, it shows that gamma irradiation has varying effects on the growth rate of $\mathrm{P}$ and $\mathrm{K}$ solubilizer multifunctional fungi. Based on the results obtained, it shows that the irradiation effect has two probabilities of increasing microbial growth rate or decreasing growth rate when compared to wild-type isolates. The response of microbes to the effects of radiation depends on the type, dose, mode of radiation. DNA is a critical target for radiation. Radiation can affect DNA directly or indirectly. Radiation affects DNA directly by deposition of energy aimed directly at the primary target. The indirect effect when there is radiation interaction with atoms or molecules in the cell or around the cell such as water. In the indirect action, radiation interaction with water will trigger the formation of free radicals. Several possibilities occur in irradiated cells. One of these is cell survival with unrepaired damage to DNA. This can cause changes in the sequence of base pairs in DNA, causing mutations [11].

Mutations are the raw material for evolution, but on the other hand, can reduce the ability of these microbes. The mutation mechanism caused by stress was first discovered in bacteria. In general, prokaryotes such as bacteria can grow rapidly and mutate more rapidly. This is a fundamental difference in the size and genetics of the prokaryotes. Therefore prokaryotes can adapt quickly to environmental changes and more easily exploit a habitat compared to eukaryotes such as fungi [12]. This is in line with the results obtained in this study. Bacterial isolates (2.5 BPK 5) after being irradiated with gamma tended to experience an increase in growth rate, both measured using optical density and from the results of TPC. Irradiation can also cause changes to physical appearance and metabolism in organisms. The changes resulting from irradiation are random. Its stability is based on the level of cell damage after irradiation at the molecular level. The degree of radiation resistance and change in living organisms varies. The type of radiation, the duration of the radiation, and the distance from the radiation source affect the resulting changes. Two types of gamma irradiation that 
are known are chronic and acute irradiation. Chronic irradiation is exposure to ionizing radiation over a long period (high cumulative dose at a low dose rate). Acute irradiation is exposure to ionizing radiation for a short period of radiation (high cumulative dose with high dose rate) [13]. Microbials are generally more resistant to mutagenesis than animals and plants. The results of this observation can be attributed to the size of the smaller microbes, the cell nucleus is also very small and is a difficult target to penetrate during irradiation. Mutagenesis in microbes is more complex than in other organisms. Microbes show the ability to protect and repair DNA. Protection against DNA includes the formation of spores (resting stage of cells) and the use of radical scavengers such as catalase, superoxide dismutase, and carotenoids. Some of the spore-forming bacteria include Bacillus sp. and Clostridium sp. resistant to irradiation. However, when nutrients are available, spore germination forms vegetative cells that are more sensitive to radiation [14], [15].

\section{Conclusion}

Gamma irradiation effects increasing the growth rate of $\mathrm{P}$ and $\mathrm{K}$ solubilizer multifunctional bacteria (1.0 BPK 5 and 2.5 BPK 5) based on optical density values. Based on the TPC result, the increase in bacterial growth rate tended to be shown by isolates 2.5 BPK 5. The effect of gamma irradiation on the growth rate of fungi was indicated by the colony diameter of the isolate 1.0 BPK 5 which was wider than the wild-type isolate and isolate 2.5 BPK 5. TPC results on fungi also showed that gamma irradiation affected the growth rate of fungi at 24, 96, 120, and 288 hours incubation time.

\section{Acknowledgments}

The authors thank all teams of the Isotope and Radiation Application Center, National Nuclear Energy Agency of Indonesia for all the facilities provided to carry out this research.

\section{References}

[1] Hayat, R., Ali, S., Amara, U., Khalid, I. (2010). Soil Beneficial Bacteria and Their Role in Plant Growth Promotion: Microbiology, 60, 579 -598.

[2] Tuhuteru, S., Sulistyaningsih, E., Wibowo, A. (2016). Effects of Plant Growth Promoting Rhizobacteria (PGPR) on Growth and Yield of Shallot in Sandy Coastal Land. Ilmu Pertanian, 1(3), 105-110.

[3] Khan, M.S., Zaidi, A., Wani, P.A. (2007). Role of Phosphate-Solubilizing Microorganisms in Sustainable Agriculture - A review. Agron Sustain Dev, 27, 29-43.

[4] Muliana, Hartono, A., Anwar, S., Dinorahman, S., Sabiham, S. (2018). Harvesting of Residual Soil Phosphorus on Intensive Shallot Farming In Brebes, Indonesia. AJAS. 40(3): 515-526.

[5] Vassilev, N., Vassileva, M., Fenice, M., Federici, F. (2001). Immobilized Cell Technology Applied in Solubilization of Insoluble Inorganic (Rock) Phosphate and P Plant Acquisition. Biores Technol, 79, 263-271.

[6] Simanungkalit, R.D.M., Husen, E., Saraswati, R. (2006). Pupuk Organik dan Pupuk Hayati. Balai Besar Penelitian dan Pengembangan Sumberdaya Lahan Pertanian. Bogor.

[7] Adrio, J.L., Demain, A.L. (2006). Genetic Improvement of Processes Yielding Microbial Products. FEMS Microbiol. Rev, 30, 187-214.

[8] Sukmadewi, D.K.T., Iswandi, A., Widyastuti, R., Citraresmini, A. (2019). Peningkatan Kemampuan Mikroba Pelarut Fosfat dan Kalium Melalui Teknik Mutasi Iradiasi Gamma. JAIR, 15(2), 67-76.

[9] Yamada, H., Takahashi, N., Okuda, S., Tsuchiya, Y. (2010). Direct Observation and Analysis of Bacterial Growth on an Antimicrobial Surface. Applied and Environmental Microbiology, 76(16), 540914.

[10] Adjari, Z., Ebrahimpour, A., Manan, M.A., Hamid, M., Mohamad, R., Arif, A.B. (2011). Nutritional Requirements for the Improvement of Growth and Sporulation of Several Strains of Monascus purpureus on Solid Cultivation. Journal of Biomedicine and Biotechnology, 2011(1), 487329. 
[11] Lehnert, S. (2007). Biomolecular Action of Ionizing Radiation.Taylor and Francis Group. USA. p. 400420.

[12] Madigan, M.T., Martinko, J.M., Bender, K.S., Buckley, D.H., Stahl, D.A. (2015). Biology of Microorganism. Ed-4. Pearson Education. USA.

[13] Hoe, P.C.K., Rahim, K.A., Saud, H.M. (2016). A Review on Microbial Mutagenesis Through Gamma Irradiation for Agricultural Application. J Sain Nuklear Malays, 28(2), 20-29.

[14] Narumi I. (2006). Carriers sterilization using $\gamma$-irradiation. In: Biofertilizer Manual. Japan: Forum for Nuclear Cooperation in Asia (FNCA) Biofertilizer Project Group. Asia Cooperation Center, Japan Atomic Industrial Forum (JAIF). pp 44-48.

[15] Naseripour, T., Shahbazi, S., Askari, H. (2014). The impact of $\gamma$-radiation on Morphological Characteristic and Antagonist Potential of Trichoderma harzianum against Rhizoctonia solani. Intern J Agric Crop Sci, 7(8), $454-461$. 